\title{
Урусова А.Б.
}

\section{Государственное регулирование на продовольственном рынке}

Северо-Кавказская государственная академия (Россия, Черкесск)

doi: $10.18411 / l j-02-2021-230$

idsp: ljournal-02-2021-230

\section{Аннотация}

В статье дается обзор определений понятия общего рынка и продовольственного рынка. Государственное регулирование продовольственного рынка представляет собой сложную взаимосвязанную систему правовых, экономических, организационных и административных мер, направленных на создание такой экономической среды, которая позволяла бы рынку проявить свои потенциальные возможности.

Ключевые слова: рынок, конкуренция, государственное регулирование, продовольственный рынок, стратегия.

\section{Abstract}

The article provides an overview of the definitions of the common market and the food market. State regulation of the food market is a complex interconnected system of legal, economic, organizational and administrative measures aimed at creating an economic environment that would allow the market to show its potential.

Keywords: market, competition, state regulation, food market, strategy.

Состояние продовольственного рынка и вопросы обеспечения населения качественными продуктами питания были и остаются наиболее актуальными проблемами для государственных и негосударственных общественных организаций.

Продовольственный рынок должен обеспечивать гарантированный доступ населения к продовольствию в необходимом количестве и ассортименте. Продовольственный рынок, как и любой другой товарный рынок, формирует связи между производителями продукции и ее потребителями на основе спроса, предложения и механизмов рыночной конкуренции.

Государственное регулирование на российском продовольственном рынке находится в процессе развития сельского хозяйства, так как Минсельхоз и Минфин, Минэкономики России и другие федеральные органы и организации в силу своих многочисленных проблем при ограниченных финансовых возможностях зачастую приводят к провалу применяемых решений.

Учитывая, что формирование развитого продовольственного рынка является объективным процессом, государство должно способствовать этому процессу путем создания максимально благоприятных условий для его функционирования, опираясь в первую очередь на механизм управления. Перспективы и эффективность государственного регулирования продовольственного рынка связаны с решением актуальных проблем по ряду направлений, в том числе:

1) устранение негативных последствий для продовольственного рынка проводимой впервые за пять-шесть пореформенных лет государственной политики;

2) осуществление закупочных и товарных интервенций вместо необоснованного централизованного импорта продукции;

3) создание благоприятных условий и стимулов в сфере кредитования и инвестирования;

4) протекционистская политика в области налогообложения и валютного регулирования; 
5) реализация эффективности механизмов на зерновом рынке с помощью уступаемых складских сертификатов на зерно;

6) Восстановление и развитие системы статистического и информационноаналитического обеспечения [1].

Возможность государственного регулирования в условиях формирования социально ориентированной рыночной экономики обусловлена характером смешанной экономики, которая характеризуется сочетанием конкуренции, свободы выбора покупателя и продавца с необходимостью обеспечения государством одинаковых “правил игры” для всех хозяйствующих субъектов на рынке и социальной защиты малообеспеченной части населения. В этих условиях развитие рыночных отношений связано с возникновением ряда противоречий, устранение которых не может осуществляться на основе рыночного саморегулирования и требует соответствующего воздействия со стороны общества в лице государства.

Комплексное воздействие государства на функционирование российского продовольственного рынка должно осуществляться на макроуровне, не затрагивая механизмов его саморегулирования на микроуровне. В отличие от ранее использовавшихся административно-командных методов управления, новая система регулирования должна быть ориентирована не на принуждение производителей и потребителей продовольствия действовать в соответствии с многочисленными директивами и задачами государственных органов, а, наоборот, на определенные обязательства государства перед ними. Именно в защите интересов производителей и потребителей должна заключаться главная цель государственного регулирования продовольственного рынка. Она подразумевает главную задачу государства в поддержании гарантированной рентабельности зернопроизводящих хозяйств и стабильного уровня цен на продовольствие путем контроля паритета цен на реализуемую хозяйствами продукцию, поставляемые им средства производства и оказываемые услуги [2].

Воздействие государства на продовольственный рынок страны должно осуществляться по следующим основным направлениям:

- регулирование производства и сбыта продукции растениеводства и животноводства;

— совершенствование межрегионального обмена и внешнеторговой деятельности с продукцией растениеводства и ее переработки;

— развитие производственной и особенно рыночной инфраструктуры.

Эти направления тесно взаимосвязаны и требуют одновременного решения, что, учитывая ограниченность финансовых и материальных ресурсов, возможно при эффективном государственном подходе к выбору конкретных форм и приоритетов распределения инвестиций, позволяющем в более короткие сроки и с наименьшими затратами решить проблему устойчивого обеспечения страны зерном за счет мобилизации потенциала собственного производства, совершенствования использования зерновых ресурсов [3; 4].

В условиях развитых рыночных отношений, в которых существует множество экономических противоречий, существуют объективные дополнительные причины для вмешательства государства в процесс реализации сельскохозяйственной продукции. Среди них природно-климатический фактор, различные уровни концентрации сельскохозяйственного производства, стимулирование товаропроизводителей, защита их интересов, а также интересов потребителей [5].

Государственное регулирование продовольственного рынка предполагает разделение полномочий федеральных и региональных органов государственной власти. Федеральные органы государственной власти сохраняют ведущую роль в ценовой, кредитной и налоговой политике, регулировании экспортно-импортных операций с сельскохозяйственной продукцией и ее переработкой. Региональные органы власти 
республики не могут изменять или отменять федеральные меры, но могут дополнять их, исходя из собственных возможностей и конкретных условий ведения продовольственного хозяйства в республике. Государственная политика в сфере производства, сбыта и использования сельскохозяйственной продукции предполагает опору на отлаженную систему регулирования деятельности хозяйствующих субъектов продовольственного рынка, что способствует развитию рыночных механизмов. Вместо разовых постановлений и указов преимущественно чрезвычайного характера должна существовать взаимосвязанная комплексная система правовых, экономических, организационных и административных мер, основанная на тщательно разработанной нормативной базе [6].

Механизм государственного регулирования продовольственного рынка должен корректироваться в зависимости от результатов мониторинга объективных процессов, происходящих в сфере производства, сбыта и использования сельскохозяйственной продукции в нужном для страны направлении и не противоречить рыночному механизму управления и общим направлениям экономической политики в агропромышленном комплексе в целом и в сельском хозяйстве в частности. В этом смысле государственное регулирование представляет собой механизм воздействия на производство, сбыт и использование продукции, соответствующий требованиям рынка и реализуемый преимущественно через экономические меры и в рамках действующего законодательства. Она осуществляется в дополнение к рыночному механизму и направлена на согласованное действие всех его элементов, но не является целенаправленной по отношению к конкретным хозяйствующим субъектам продовольственного рынка. Ее границы должны определяться сферой действия объективных экономических законов и конкретными задачами, стоящими перед государством в области надежного обеспечения продовольственных потребностей страны на конкретный период. В зависимости от сложившейся ситуации формы и методы государственного регулирования могут быть самыми разнообразными, но они должны исходить из экономической свободы хозяйствующих субъектов продовольственного рынка, их интересов и быть направлены на обеспечение продовольственной независимости страны от внешних источников доходов [7].

Таким образом, государственное регулирование продовольственного рынка представляет собой сложную взаимосвязанную систему правовых, экономических, организационных и административных мер, направленных на создание экономической среды, которая позволила бы рынку проявить свой потенциал.

$$
* * *
$$

1. Абрамов А.Е. Компании с государственным участием на российском рынке: структура собственности и роль в экономике / А.Е. Абрамов, А.Д. Радыгин, М.И. Чернова // Вопросы экономики. - 2016. - № 12. - С.61-87.

2. Андрианов В. Механизмы саморегуляции рыночной экономики на микроэкономическом уровне /В. Андрианов// Общество и экономика. - 2008. - № 2. - С.5-35.

3. Аничин В. Факторы спроса на продовольственном рынке / В.Аничин, А.Середин // Экономист. 2011. - № 4. - С.92-96.

4. Карпушин Е. Развитие рынка микрофинансовых организаций России: конфликт интересов инвесторов, заемщиков и государства /Е. Карпушин// Вопросы экономики. - 2016. - № 9. - С.150158.

5. Маркеева А.В. Проблемы становления и перспективы развития российского рынка государственных заказов /А.В. Маркеева// Соц.-гуман. знания. - 2010. - № 6. - С.167-180.

6. Ткач А.В. Потребительская кооперация в инфраструктуре продовольственного рынка / А.В. Ткач, А.С. Жуков, А.С. Нечитайлов // Фундаментальные и прикладные исследования кооперативного сектора экономики. - 2017. - № 1. - С.25-30.

7. Хачатурян А. Человеческий капитал как основа выбора рыночной модели /А.Хачатурян// Проблемы теории и практики управления - 2015. - № 10. - С.27-35. 